\title{
Modeling River Ecosystem Vulnerability Assessments Due to Climate Change: Case Study of Armenia
}

\author{
Alla S. Aleksanyan ${ }^{1}$, Surik Kh. Khudaverdyan², Ashok Vaseashta ${ }^{3,4 *}$ \\ 'Department of Geo-Botany and Ecological Physiology, Institute of Botany of NAS Armenia, \\ Acharyan 1, Yerevan, 0063 Armenia \\ ${ }^{2}$ Design and Production of Radio Devices, Armenian National Polytechnical University, \\ Teryan 105, Yerevan, 0009 Armenia \\ ${ }^{3}$ Institute for Advanced Sciences Convergence \& International Clean Water Institute, NUARI, Northfield, VT 05663 \\ ${ }^{4}$ Molecular Science Research Center, Claflin University, Orangeburg, SC 29115 USA
}

Received: 7 August 2014

Accepted: 2 November 2014

\begin{abstract}
Water resources are an integral part of the global hydrologic cycle and are considered among the natural systems most vulnerable to climate change. Research indicates that severe problems related to water will affect the globe around 2030, which will further intensify to attain its peak by 2100 unless a different water management trajectory is strategically implemented. To conduct an accurate climate change impact assessment it is necessary to conduct parametric analysis for vulnerability to assess for each system by constructing a conceptual hydrogeological model that is then transferred to a mathematical model of overall water resources. We present here a case study outlining plausible impacts of climate change on water resources of Armenia, particularly on river ecosystems. Based on this initial study, we propose certain recommendations for the future to reduce, if not reverse in its entirety, the vulnerability trajectory. We further conclude that vulnerability assessment of water resources resulting from climate change, as proposed here, can be applied for different countries and will be of considerable interest worldwide.
\end{abstract}

Keywords: climate change, vulnerability, water resources, assessment, Armenia

\section{Introduction}

Water is fundamental to sustaining life. Despite the abundance of water globally, access to clean drinking water is becoming scarce at a rapid rate for multiple reasons, with urbanization being foremost. This causes water resource scarcity and increases water stress, both in large cities as well as in many regions of the world with less infrastructure and support. Population growth and its associated demand on water supply poses a significant challenge in maintain-

*e-mail: prof.vaseashta@ieee.org ing adequate water quality in various sectors. Most waterstressed and lower per capita income regions also suffer additional socio-political issues. Unsustainable increases in water demand have caused growing competition for water resources, tensions among different users, water quality deterioration, and degradation of aquatic ecosystems. Addressing all these issues requires a multi-disciplinary, inter-sectorial, and participatory approach to efficiently manage water resources.

The Republic of Armenia is a mountainous country with total area $29,800 \mathrm{~km}^{2}$ with semiarid climate. About $75 \%$ of total 2D land area is located $1,500 \mathrm{~m}$ above sea 
level. For a country with so many important rivers and lakes, average annual rainfall in Armenia is 592 mm, but it is distributed unevenly across the country. In the Ararat Valley and Meghri region, the total annual precipitation is about 200 to $250 \mathrm{~mm}$, while in the mountains and highlands it reaches 1000 to $1100 \mathrm{~mm}$. The rivers in Armenia are tributaries of the main rivers of the southern Caucasus, namely the Araks and the Kura. Approximately $76 \%$ of the total territory is part of the Araks basin and the remaining $24 \%$ of the Kura basin. Total outflow is equal to the internal renewable water resources (IRWR). The outflow to Georgia through the Debet River is estimated to be at approx. 0.89 $\mathrm{km}^{3} /$ year and outflow to Azerbaijan through the Agstay River at about $0.35 \mathrm{~km}^{3} /$ year; both rivers are located in the Kura basin. The total outflow to Azerbaijan through the Araks and its tributaries (Arpa, Vorotan, and Voghji) is estimated at about $5.62 \mathrm{~km}^{3} /$ year. The Araks River forms the border between Turkey and Armenia and, further downstream, between the Islamic Republic of Iran and Armenia, where it flows into Azerbaijan, eventually joining the Kura River about $150 \mathrm{~km}$ before its mouth at the Caspian Sea. The border flow of the Akhuryan (with Turkey) is estimated at $1.03 \mathrm{~km}^{3} /$ year and the Araks at $0.79 \mathrm{~km}^{3} /$ year. Half of the border flow is accounted for in Armenia's water balance, bringing the total actual renewable water resources to $7,769 \mathrm{~km}^{3} /$ year.

Average annual total river runoff is $6,250 \mathrm{mln} \cdot \mathrm{m}^{3}$, from which $3,029 \mathrm{mln} \cdot \mathrm{m}^{3}$ is formed from springs and ground waters. About $940 \mathrm{mln} \cdot \mathrm{m}^{3}$ is formed from the frontier rivers Araks and Ahuryan. The 14 sub-basins of the two main river basins (Kura and Araks) have been grouped into five basin management areas: Akhuryan, Northern, SevanHrazdan, Ararat, and Southern basins. About 9,500 rivers and streams with total length of $23,000 \mathrm{~km}$ flow in Armenia. Out of that number, 379 rivers are around 10-100 $\mathrm{km}$ long, and seven, namely the Akhuryan, Debet, Vorotan, Hrazdan, Aghstev, Arpa, and Metsamor-Kasakh, are longer than $100 \mathrm{~km}$ [1]. The internal renewable surface water resources are estimated to be at $3,948 \mathrm{~km}^{3} /$ year and the internal renewable groundwater resources are estimated to be at a rate of $4,311 \mathrm{~km}^{3} /$ year. The overlap between surface water and groundwater is thus estimated to be at a rate of $1,400 \mathrm{~km}^{3} /$ year. This gives a total of $6,859 \mathrm{~km}^{3} /$ year of annual internal renewable water resources. Natural water resources amount to $4,017 \mathrm{mln} \cdot \mathrm{m}^{3} /$ year, from which 1,595 $\mathrm{mln} \cdot \mathrm{m}^{3}$ comes from springs, $1,434 \mathrm{mln} \cdot \mathrm{m}^{3}$ from drainage outflow, and $0.988 \mathrm{mln} \cdot \mathrm{m}^{3}$ from groundwater [2].

Some of these rivers originate from runoff and subterranean springs, while others are fed primarily by melting snow and ice. Lake Sevan - one of the largest high-altitude lakes in the world - along with more than 100 small mountain lakes, stores snowmelt and runoff, spreading river flow from the wet seasons into the dry seasons. Most precipitation (on an average of $\sim 37 \%$ of the annual total) falls in March, April, and May, while the least precipitation (17\%) falls in December, January, and February. a)

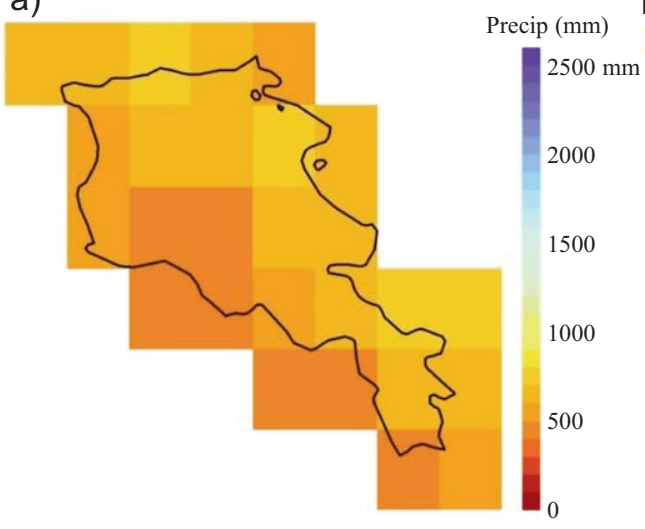

c)

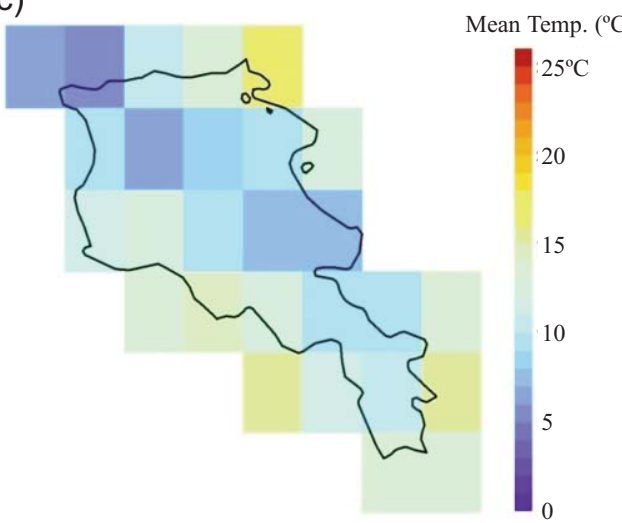

b)

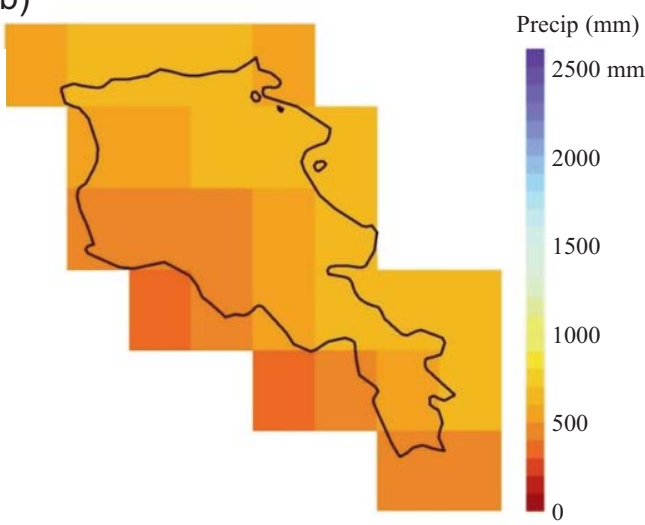

d)

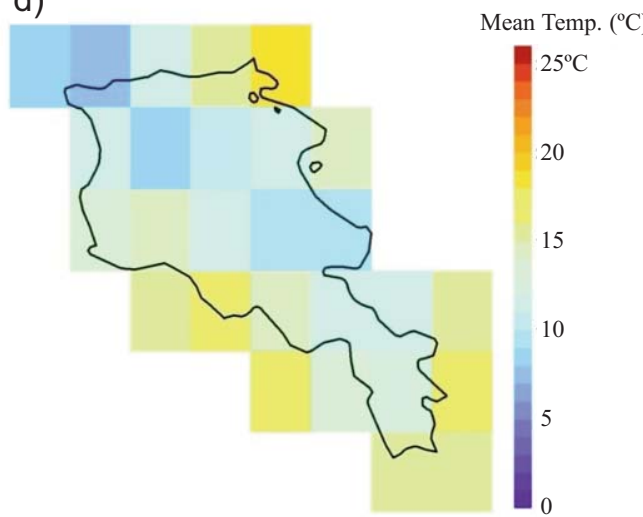

Fig. 1. Annual air temperature $\left({ }^{\circ} \mathrm{C}\right)(\mathrm{a}, \mathrm{b})$ and precipitation (\%) (c, d) changes in 2030-2070 and 2070-2100, according to the PRECIS model under A2 scenario of IPCC. 
With such a high degree of variation in altitude, temperature, and precipitation levels, Armenia has several climates and as a result, one area of the country may be at risk of drought while another area may suffer flood conditions [3]. The water resources of Armenia are distributed very unevenly in terms of spatial and seasonal distribution. Around $50 \%$ of the total volume of river flow is subject to significant annual variations (the flow in a given dry year is $<65 \%$ than in an average year). In addition to annual variations, there are also significant seasonal variations in river flow. Around $55 \%$ of the total river flow in a normal year comes from spring snow melt and rainfall, and the ratio for maximum to minimum flow can reach up to 10:1 [4]. Water resources of Armenia are used as sources for hydro-electric power, irrigation, and routine water supply, therefore the estimation of their vulnerability with possible climate change and realization of necessary adaptation measures are extremely important. Armenia is also considered one of the best zones for climate change research, due to mountainous landscapes, well expressed vertical zonation, and diversity of climate, soil conditions, flora, and vegetation, coupled with a rich geological history. Furthermore, for the last 80 years the average temperature in Armenia has increased by $1.03^{\circ} \mathrm{C}$ and the precipitation level has decreased by approximately $6 \%$, indicating that the observed impact may be linked to global climate change. According to the climate change scenarios developed for Armenia, the regional temperature is predicted to increase by $4.8-5.7^{\circ} \mathrm{C}$ and reduction in precipitation levels is estimated to be in the range of 1 $27 \%$ by 2100 (Fig. 1) [5].

\section{Methods}

While assessing the vulnerability of water resources, trends of river flow and snow cover changes were analyzed for the period of 1991-2006 to project climate change through year 2030 (short term), year 2070 (mid-term), and year 2100 (long-term). Based on observed changes in river flow in 1991-2006 and select climate change scenarios, the vulnerability of annual river flow of individual river basins in the Republic of Armenia is projected from a short to a long time-frame, as mentioned earlier. Increased river flow is expected as a result of a significant increase in atmospheric precipitation only in the Vorotan and Voghji river basins, while river flow will decline in other river basins. Significant decreases in flow are expected in several rivers of Lake Sevan basin, viz. Vedi, Arpa, Akhuryan, Sevjur, and lower flow of rivers in the north-eastern part of the country. If the climate change scenario as forecast becomes a reality, the total river flow in Armenia will be reduced by approximately $6.7 \%$ by $2030, \sim 14.5 \%$ by 2070 , and $\sim 24.4 \%$ by 2100 [5].

For rivers, the Water Evaluation and Planning Model (WEAP) are used and will be used to relate climate (i.e. precipitation and temperature) to model flow-stream. The WEAP model is an IWRM model that integrates water supply generated through watershed scale hydrologic processes with a water management model driven by water demands and environmental requirements. The WEAP model includes an irregular-grid, water balance model that can account for hydrologic processes within a watershed system and can capture the propagating and non-linear effects of water withdrawals for different uses [6].

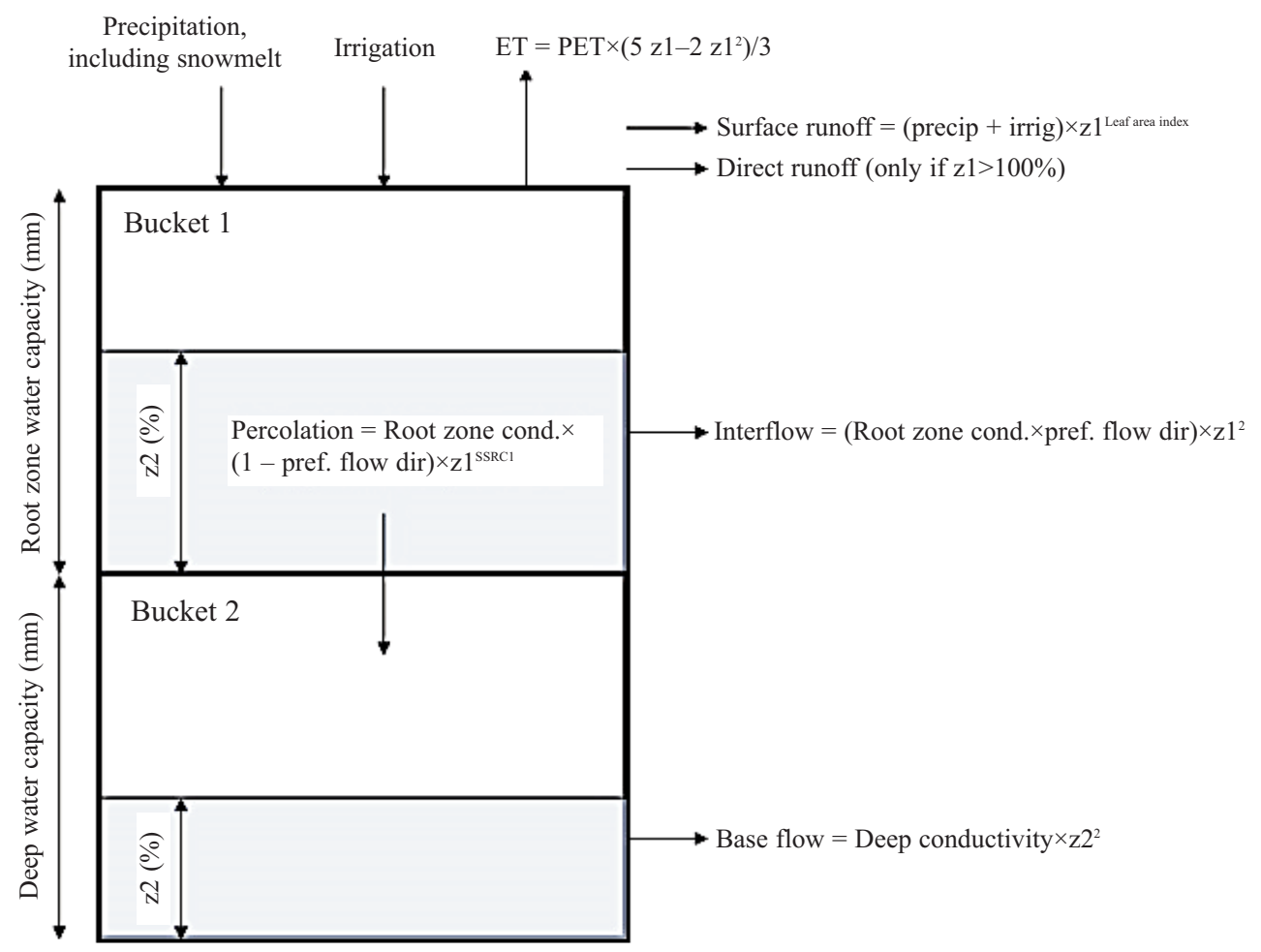

Fig. 2. Soil moisture method. 
The use of the WEAP model includes the following several steps:

1. Determination of the study - defining the time frame, special limits, and the structure of the problem.

2. Current Accounts - the basic definition of the water system as it currently exists and forms the foundation of all scenario analyses. It represents the actual water demand, load of pollutants, and the sources and resources for the system. This can be perceived as the calibration step in the development of the application.

3. Scenarios - describes how a system might evolve over a period of time in a set of particular conditions. These conditions depend on socio-economic settings, policy regulations, and/or implementation of technology. The scenarios represent an image of the system projecting the future water demand and the water supply after changing conditions such as costs, future politics, climate, etc. These alternative scenarios can be compared to each other, which offers a useful guideline to develop policies for water systems from local to regional scales.

4. Evaluation - the scenarios will be evaluated taking certain aspects into account, such as the availability of water, the costs and the profit, the environmental aspect, and the sensitivity to uncertainty in the key variables [7].

A one-dimensional, two-storage soil water accounting scheme uses empirical functions that describe evapotranspiration (ET), surface runoff, sub-surface runoff or interflow, and deep percolation models. WEAP is not spatially explicit, but spatially implicit, and hence it does not model the exact real landscape. The sequence of sub-catchments and demand sites are critical, as each sub-catchment is treated as a "two-bucket" system. For each sub-catchment, a mass balance equation is written as:

$$
\begin{aligned}
S w_{j} \frac{d z_{l, j}}{d t} & =P_{e}(t)-\operatorname{PET}(t) k_{c, j}(t)\left(\frac{5 z_{l, j-2 z_{l, j}^{2}}^{2}}{3}\right)-P_{e}(t) z_{l, j}^{\frac{L A l_{j}}{2}}- \\
f_{j} k_{j} z_{l, j}^{2} & -\left(l-f_{j}\right) k_{j} z_{l, j}^{2}
\end{aligned}
$$

Climate variables for the chosen time span (e.g. decade, month, year):

- $\quad P$ - precipitation (mm)

- $\quad P E T$ - potential evapotranspiration $(\mathrm{mm})$, which can be calculated from mean temperature $\left(0^{\circ} \mathrm{C}\right)$, relative humidity $(\%)$, mean wind velocity $(\mathrm{m} / \mathrm{s})$, melting and freezing temperatures $\left(-50^{\circ} \mathrm{C}\right.$ and $50^{\circ} \mathrm{C}$ by default), and geographical coordinates of catchment (using PenmanMonteith equation because it can estimate the evapotranspiration accurately and the climatic input variables)

- Various soil/vegetation parameters

- Area of catchment $\left(\mathrm{km}^{2}\right)$ and sub-catchments, if catchment is divided by land cover type

- $K_{c}-$ crop/plant coefficient for each fractional land cover

- $z, z^{2}$ - relative soil water storage in upper and lower storages at the starting point in time (\%)

- $D_{w}-$ deep-water storage capacity $(\mathrm{mm})$

- $S_{w}$ - soil water capacity $(\mathrm{mm})$

- $k_{j}$ - the conductivity rate of the lower storage ( $\mathrm{mm} /$ time)

- $k_{j}$ - an estimate of upper storage conductivity (mm/time)
Table 1. Water balance elements of Armenia's water resources and their forecasted changes.

\begin{tabular}{|c|c|c|c|}
\hline Year & $\begin{array}{c}\text { Precipitation, } \\
\text { billion } \mathrm{m}^{3}\end{array}$ & $\begin{array}{c}\text { Evaporation, } \\
\text { billion } \mathrm{m}^{3}\end{array}$ & $\begin{array}{c}\text { River flow, } \\
\text { billion } \mathrm{m}^{3}\end{array}$ \\
\hline $1991-2006$ & 17.60 & 10.50 & 7.10 .2014 \\
\hline 2030 & 17.29 & 10.67 & 6.62 \\
\hline 2070 & 16.83 & 10.76 & 6.07 .2014 \\
\hline 2100 & 16.26 & 10.89 & 5.37 \\
\hline
\end{tabular}

- $f_{j}$ - quasi-physical tuning parameter related to soil, land cover type, and topography that fractionally partitions water either horizontally, $f_{j}$, or vertically $\left(1-f_{j}\right)$.

- $L A I_{j}$ - the leaf and stem area index, with the lowest $L A I_{j}$ values assigned to the land cover class that yields the highest surface runoff response, such as bare soils.

That is, the soil moisture in a sub-catchment is the precipitation that falls less than evapotranspiration and the amount of water that leaves the catchment via surface runoff or sub-surface flows. To calculate stream flow the model needs information for every sub-catchment, including the number of sub-catchments, their order and area, and climate variables as used to model WEAP. For modelling most of the parameters, either the default values are used or the ones that are calibrated. Water consumption (demand) at different points of a river are specified as monthly values $\left(\right.$ in $\mathrm{m}^{3}$ ). There are three methods presented in the WEAP model for simulating catchment processes. These are:

\section{Irrigation Demands Only}

The demands-only method is the simplest of all methods, very similar to versions used by the Food and Agriculture Organization (FAO) Crop Requirements Approach. It uses crop coefficients to calculate the potential evapotranspiration in the catchment, then determines any irrigation demand that may be required to fulfill that portion of the evapotranspiration requirement that rainfall cannot meet. It does not simulate runoff or infiltration processes, or track changes in soil moisture.

\section{Rainfall Runoff}

The rainfall runoff method also determines evapotranspiration for irrigated and rain-fed crops using crop coefficients, the same as in the irrigation demands only method. The remainder of rainfall not consumed by evapotranspiration is simulated as runoff to a river, or can be proportioned among runoff to a river and flow to groundwater via catchment links.

\section{Soil Moisture Method}

The Soil Moisture method is the most complex of all methods, representing the catchment with two soil layers, as well as the potential for snow accumulation. In the upper 
Table 2. Total projected river flow change under climate change.

\begin{tabular}{|c|c|c|c|}
\hline \multirow{2}{*}{$\begin{array}{c}\text { Time } \\
\text { period }\end{array}$} & \multirow{2}{*}{$\begin{array}{c}\text { Flow } \\
\text { million } \mathrm{m}^{3}\end{array}$} & \multicolumn{2}{|c|}{ Change in flow } \\
\cline { 3 - 4 } & & million $\mathrm{m}^{3}$ & $\%$ \\
\hline Current & $4,994.4$ & 0 & 0 \\
\hline 2030 & $4,660.9$ & -333.5 & -6.7 \\
\hline 2070 & $4,269.9$ & -724.5 & -14.5 \\
\hline 2100 & $3,777.6$ & -1216.8 & -24.4 \\
\hline
\end{tabular}

soil layer, it simulates evapotranspiration considering rainfall and irrigation on agricultural and non-agricultural land, runoff and shallow interflow, and changes in soil moisture. This method allows for the characterization of land use and/or soil type impacts to these processes. Base flow routing to the river and soil moisture changes are simulated in the lower soil layer. Correspondingly, the soil moisture method requires more extensive soil and climate parameterization to simulate these processes.

For Armenia we've chosen the soil moisture method, because it offers the most comprehensive analysis of river basins, therefore more accurate modeling of hydrological characteristics. Soil moisture is an important factor in selection criteria due to the fact that the input parameters of atmospheric precipitation and air temperature change the previously calculated values. Furthermore, the method also allows simulation of river flow-based climate change scenarios. The soil moisture water balance calculation method included in the equations of the conceptual scheme are presented in Fig. 2.

\section{Discussion}

Water quality monitoring provides data for assessing the quality of water to protect it for drinking, fishing, boating, irrigation, stock watering, and supporting aquatic wildlife. Based on the selected climate change scenarios, the vulnerability of the annual river flow of individual river basins in Armenia was assessed for 2030-2100 (Fig. 3) [5].

In summary - based on our model, forecasts for Armenia show that the water balance changes in river flow for the entire country of Armenia, compared to the average for 1961-1990, will decrease by 0.48 billion $\mathrm{m}^{3}$ by 2030 , 1.03 billion $\mathrm{m}^{3}$ by 2070 , and 1.73 billion $\mathrm{m}^{3}$ by 2100 (Table 1). Lower precipitation levels combine with higher average temperatures to increase evaporation rates and reduce winter snowpack and spring runoff: As a result, less water reaches streams and rivers. Climate change will reduce river flow, lake levels, and, eventually, groundwater reserves. Armenia's total river flow is projected to drop 7\% by 2030 and $24 \%$ by 2100 (Table 2). For a number of Armenia's rivers the greatest cause of reduced flow will be less accumulation of snow and ice, with lower winter precipitation and slightly higher winter temperatures.
Over the last 10 years the Republic of Armenia has recorded significant legislative and institutional achievements in terms of water resource management and protection, the main direction of which was introduction and application of the principles of IWRM in the country. This has been supported by a number of initiatives in cooperation with international institutions [8]. Currently the water sector reforms are in the process of decentralization of the water resources management and adaptation functions. This is with the aim of more efficient integrated management of water resources at basin level for the benefit of individual water users as well as for the overall best use of resources at national and regional levels. But all these project results are not insufficient and we need to carry out targeted measures and taking into consideration possible and direct impacts of climate change.

a)

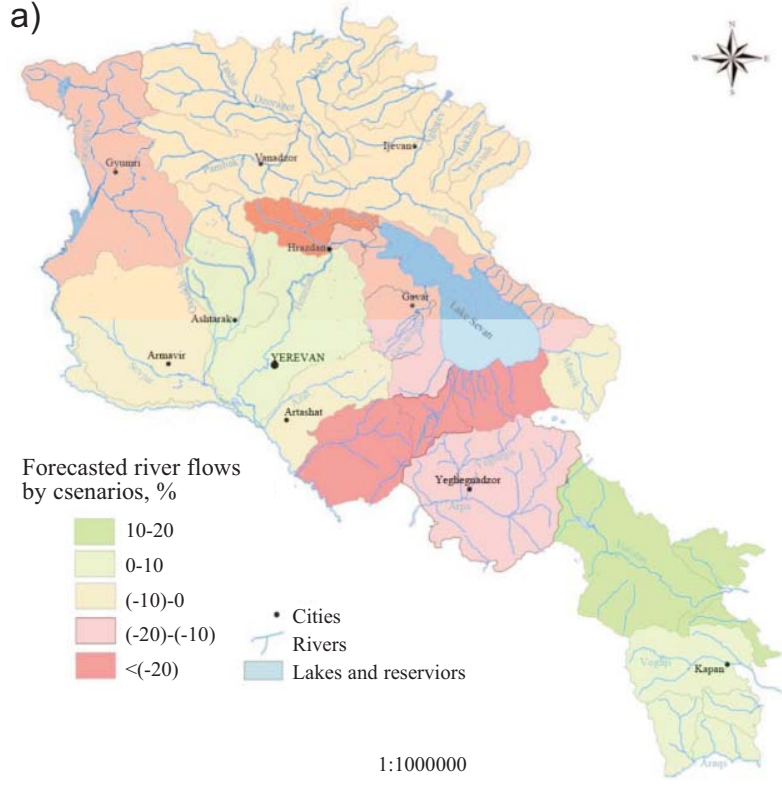

b)

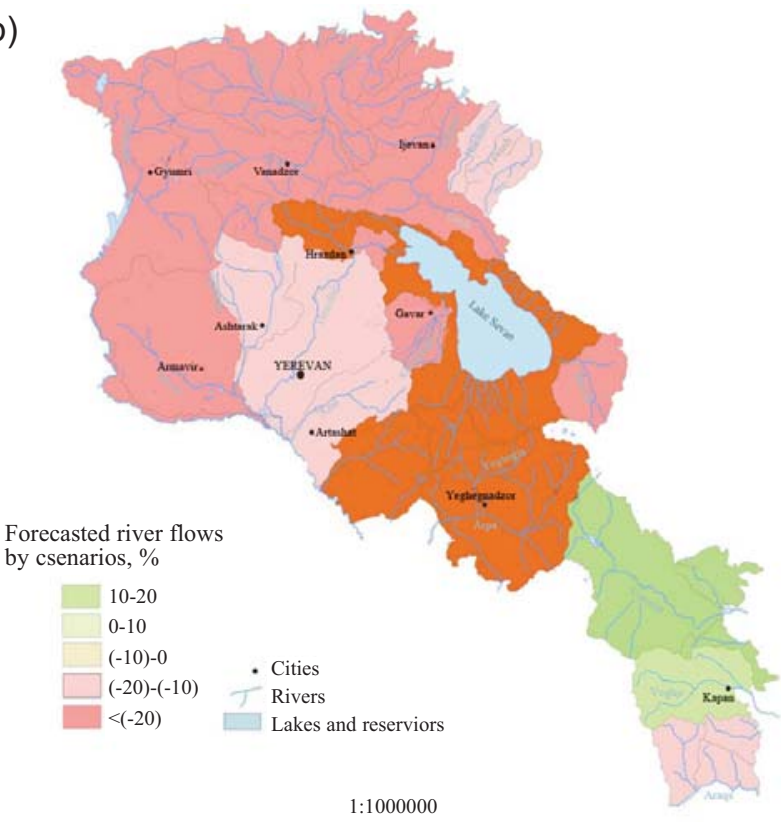

Fig. 3. a) Forecasted changes in river flow by river basin (2030). b) Forecasted changes in river flow by river basin (2100). 
These future measures will include:

- Exact assessment of water resources

- Legal and organizational measures

- Institutional mechanisms

- Technical measures

To mitigate the consequences of climate change on water resources and adapt the economy to the new natural conditions, we propose implementation measures for accurate assessment of water reserves, undertaking institutional and technical measures for efficient use of water resources, and exercising water management strategies for extensive storage of water resources and reduction of losses due to leakage. Changes in water resource availability can be expected as consequences of climate change, population growth, economic development, and environmental considerations. An advanced, physically based, distributed, hydrological WEAP model will be applied to determine the internal and external renewable water resources for the current situation and under future changes. Subsequently, a water allocation model is used to combine the renewable water resources with sectorial water demands.

The WEAP model is a useful tool for integrated water resources management that goes a step beyond conventional supply-oriented water simulation models. It simulates a broad range of natural and engineered components of a water system and allows us to evaluate a full array of water development and management options based on a context defined by vulnerability and climate change impacts, water rights and allocation priorities, ecosystem requirements, reservoir operations, hydropower generation, and pollution tracking. The WEAP model has been applied from single sub-basins to complex river systems in many countries (United States, Spain, Italy, Germany, Lebanon, Israel, Egypt, Mexico, South Africa, China, India, Peru, Chile, etc.).

The case study review of the WEAP model in some countries confirms that this model as a forecasting tool can simulate water demand, supply, flows, storage, pollution, treatment, and discharge [9-13]. For political analysis, WEAP can take multiple and competing uses of water systems into account and can be useful for different water resources and environments. The current case study in the South Caucasus region is the Alazani (Ganikh) river basin of Georgia [14]. Currently a qualitative and quantitative analysis for the Arpa River in Armenia are being done using the WEAP model. The results will be described in a future extended publication, and also will be presented at the $3^{\text {rd }}$ national communication meeting of Armenia and will be useful for planning management and assessment of vulnerability action plans of other water resources in Armenia.

\section{Conclusions}

Our objective is to demonstrate that WEAP is advantageously employed as an analytical tool to study the impacts of climate change on water resources of Armenia and to reduce their vulnerability. Adaptation measures for river basins of Armenia include demand-side conservation measures and possibly increased storage to address increased variability and shortfalls in high demand-months. For effective climate change adaptation planning in these basins it is imperative that trans-national river management plans are implemented.

This field of research needs additional research that includes:

- Research conditions of resources of underground waters.

- Predict climate change impact on stocks

- Forecast impacts of climate change on water quality

This hydrologic model needs to be validated for a long time period, making adjustments as necessary in some soil parameters in order to improve the accuracy in the hydrologic response of the whole basin, considering that the hydraulic conductivity and initial storage increase when the available water in the soil layers increase. In other words, the hydraulic conductivity should be larger in a period with significant rainfall than a period with little to no rainfall. The integration of WEAP hydrological flow prediction capabilities into the existing WEAP model of basins of Armenian rivers will create a powerful tool for regional planners. The model could be useful in generating inflows to the basins under various sequences of future precipitation. These inflows could be used in the WEAP water management model to assess the result for basin stakeholders on different scenarios of basin operations.

The WEAP model uses statistical data, maps, satellite photos, and different GIS layers. The resulting data allow us to forecast not only changes of river flow, temperature, and precipitation on the impacts of climate change, but also indexes of expected pollution of water resources. As a path forward, we anticipate that in future to be able to present other methods and models for river ecosystem vulnerability assessment from climate change for Armenia and adjacent countries.

\section{References}

1. CHILINGARYAN L., MNATSAKANYAN B., AGHABABYAN K., TOQMAJYAN H. Hydrography of rivers and lakes of Armenia. Yerevan, pp. 49, 2002 [In Armenian].

2. National Statistical Service of the Republic of Armenia. Environment and natural resources of the Republic of Armenia. Statistical Collection. 135, 2003.

3. MOVSISYAN V. Forecasting evaluation and complex management of water resources of Republic of Armenia. 206. 2003 [In Armenian].

4. Irrigation in the Middle East region in figures. FAO water reports 34, 423, 2009.

5. Second National Communication on climate change of Republic of Armenia. 120, 2010.

6. RANDALL D.A., WOOD R.A., BONY S., COLMAN R., FICHEFET T., FYFE J., KATTSOV V., PITMAN A., SHUKLA J., SRINIVASAN J., STOUFFER R.J., SUMI A., TAYLOR K.E. Climate Models and Their Evaluation.: Climate Change: The Physical Science Basis. Contribution of Working Group I to the Fourth Assessment Report of the Intergovernmental Panel on Climate Change. Cambridge University Press, Cambridge, New York. pp. 589-662, 2007. 
7. URL - www.weap21.org

8. Water Sector note of Republic of Armenia. 121, 2011.

9. HAMLAT A., ERRIH M., GUIDOUM A. Simulation of Water Resources Management Scenarios in Western Algeria Watersheds using WEAP Model. Arab. J. of GS, 6, (7), 2225, 2013.

10. HOFF H., BONZI CH., JOYCE B., TIELBÖRGER K. A Water Resources Planning Tool for the Jordan River Basin. Water J. 3, (3), 718, 2011

11. JUIZO D., LIDEN R. Modeling for trans-boundary water resources planning and allocation: the case of Southern Africa. Hydrology and Earth System Sciences. 14, (11), 2343, 2010.
12. SANDOVAL-SOLIS S., TEASLEY R., MCKINNEY D., THOMAS G. A., PATINO-GOMEZ C. Collaborative Modeling to Evaluate Water Management Scenarios in the Rio Grande Basin. J of Amer. Water Res. Assoc., 49, (3), 639, 2013.

13. YILMAZ B., HARMANCIOGLU N. B., Multi-criteria decision making for water resource management: a case study of the Gediz River Basin, Turkey. Water SA, 36, (5), 4359, 2010.

14. Regional Climate Change Impacts Study for the South Caucasus Region Tbilisi, Georgia. 62, 2011. 
